\title{
Effects of a power plant closure on home ranges of green turtles in an urban foraging area
}

\author{
Tomoharu Eguchi ${ }^{1, *}$, Jessica Bredvik ${ }^{2}$, Suzanne Graham ${ }^{3}$, Robin LeRoux ${ }^{1}$, \\ Brendan Saunders $^{3}$, Jeffrey A. Seminoff ${ }^{1}$ \\ ${ }^{1}$ Southwest Fisheries Science Center, National Marine Fisheries Service, National Oceanic and Atmospheric Administration, \\ La Jolla, CA 92037-1508, USA \\ ${ }^{2}$ United States Navy, Naval Facilities Engineering Command Southwest, San Diego, CA 93132-5190, USA \\ ${ }^{3}$ United States Navy, Naval information Warfare Center, San Diego, CA 92152-5001, USA
}

\begin{abstract}
A natural experiment was conducted to determine effects of a fossil-fueled power plant on home ranges of east Pacific green turtles Chelonia mydas in an urban foraging ground. The power plant, located in south San Diego Bay, California, USA, co-existed with a resident foraging aggregation of $\sim 60$ green turtles for $\sim 50 \mathrm{yr}$. It was decommissioned during a long-term green turtle monitoring study, thus providing a rare opportunity to evaluate how the cessation of warm-water effluent affected turtle movements and habitat use in the area. During pre- and postdecommissioning of the power plant, 7 and 23 green turtles, respectively, were equipped with GPS-enabled satellite transmitters. Useful data were obtained from 17 turtles (4 for pre- and 13 for post-decommissioning). Core use areas ( $50 \%$ utilization distribution [UD]) increased from 0.71 to $1.37 \mathrm{~km}^{2}$ after the power plant decommissioning. Increase in post-power plant $50 \%$ UD was greater during nighttime (0.52 to $\left.1.44 \mathrm{~km}^{2}\right)$ than daytime (1.32 to $\left.1.43 \mathrm{~km}^{2}\right)$. Furthermore, UDs moved from the effluent channel to an area closer to seagrass pastures, a presumed foraging habitat of the turtles. The observed expansion of green turtle home ranges may increase turtle-human interactions, such as boat strikes, within the foraging ground; this underscores how seemingly innocuous human actions contribute to inadvertent consequences to wildlife. Possible management and conservation actions include increasing awareness of the public regarding turtle presence in the area through signage and education as well as legislating for a reduction in boat speeds in select areas of the bay.
\end{abstract}

KEY WORDS: Argos - Anthropogenic effects - Chelonia mydas - Eastern Pacific Ocean · Fastloc-GPS · Movements · Satellite telemetry

\section{INTRODUCTION}

For centuries, humans have inhabited coastal areas because they provide accessibility to sustenance from coastal and nearshore areas, provide opportunities for trade and transportation, and have a moderate climate compared to inland areas. The number of people who reside in coastal areas is increasing around the globe (Small \& Nicholls 2003), resulting in a rise in human impacts on coastal environments

\footnotetext{
${ }^{*}$ Corresponding author: tomo.eguchi@noaa.gov
}

(Halpern et al. 2015). Nearshore coastal environments also provide ideal habitats for marine organisms because of high productivity (Mann \& Lazier 1996). An unavoidable consequence of these phenomena is a spatial overlap of aquatic wildlife and human use, which can happen as a simple co-occurrence or cause injury/death (e.g. ship strikes on large whales, shark attacks on surfers, light pollution on turtles at nesting beaches, bycatch of untargeted species in fisheries, etc.). To reduce such potential Creative Commons by Attribution Licence. Use, distribution and reproduction are unrestricted. Authors and original publication must be credited.

Publisher: Inter-Research · www.int-res.com 
harm to animals, a wide variety of conservation and protective measures have been developed as mitigation strategies to promote sustainable human activities. For example, to reduce the number of ship strikes on the endangered North Atlantic right whale Eubalaena glacialis, the shipping lanes along the eastern seaboard of the USA have been modified and ship speed decreased (Vanderlaan \& Taggart 2007, Silber et al. 2012). For another example, to reduce the negative effects of light on nesting turtles and emerged hatchlings, street lights have been modified in parts of Florida, USA, while providing sufficient lighting for human activities (Salmon 2006). To make these mitigation efforts successful, the development of effective conservation and protective measures requires knowledge of an organism's habitat use and behavior as well as spatial and temporal distribution of anthropogenic threats (Ross et al. 2011).

Interactions between humans and wildlife are dynamic in temporal and spatial scales. A recent emphasis in the management of these interactions considers the predictable variability in animal distributions (e.g. Lewison et al. 2015, Maxwell et al. 2015, Becker et al. 2016, Dunn et al. 2016, Eguchi et al. 2017). However, such an approach requires a substantial amount of knowledge about animals' spatial biology. One example is the advisory tool for the Hawaii-based shallow-set longline fishery targeting swordfish Xiphias gladius, where areas of higher likelihood of interactions with loggerhead turtles Caretta caretta and leatherback turtles Dermochelys coriacea are provided daily based on the observed associations between sea surface temperature and turtle movements (TurtleWatch; Howell et al. 2008, 2015). A similar approach has been developed to reduce potential fishing interactions between loggerheads and the California-based drift gillnet fishery (Welch et al. 2019). Relationships between organisms and environment, however, are not constant across their entire distribution (e.g. foraging vs. calving grounds for whales). Consequently, a relationship that was found in one area may not be applicable to another area within the species' range. Therefore, effective management of a protected species requires acquiring sufficient information on the species and its environment from the specific area in which management actions are needed.

Sea turtles are a taxon that distributes widely and interacts with humans through much of their range. Movements among various habitats are reported for all 7 species of sea turtles (reviewed by Plotkin 1996, Bolten 2003). After emerging from their nests, hatchlings generally distribute in the high seas until moving into neritic environments, eventually finding a foraging ground where they settle and often maintain residency (Pritchard 1997, Musick \& Limpus 1997). Juvenile and adult marine turtles seem to have high philopatry to their foraging grounds in tropical and temperate coastal regions (Broderick et al. 2007, Shaver \& Rubio 2008, Schofield et al. 2010, Shimada et al. 2016). At a foraging ground, home ranges of individual turtles often vary in size and shape and may be affected by density and distribution of prey and physical environment (Mendonça 1983, Renaud \& Carpenter 1994, Lamont et al. 2015, Dujon et al. 2018).

In this study, we monitored movements of green turtles Chelonia mydas in a highly urbanized foraging area in San Diego Bay (SDB), located at the southern end of California, USA. The green turtle in the Eastern Pacific nests along the mainland and islands of Mexico and Central and South America, and their known coastal foraging grounds range from Chile to the USA (Seminoff et al. 2015). Green turtles have been sighted in SDB since the mid-1800s (Stinson 1984, Benson \& Dutton 2012). Ongoing genetic studies and satellite telemetry data show that this foraging aggregation is part of the Mexican breeding stock, most likely originating from nesting beaches in the Revillagigedo and Tres Marias Archipelagos and on mainland, Michoacan, Mexico (Dutton et al. 2019; Fig. 1). The nesting female abundance has been increasing steadily since the mid-1990s, which is likely due to the nesting beach protections initiated in the late 1970s (Seminoff et al. 2015). SDB serves as a year-round foraging site for $\sim 60$ green turtles (Eguchi et al. 2010, National Oceanic and Atmospheric Administration [NOAA] unpubl. data). A continuous recruitment of juveniles indicates that $\mathrm{SDB}$ is a natural foraging ground for east Pacific green turtles (Benson \& Dutton 2012). Since the 1970s, green turtles in SDB were known to aggregate near the South Bay Power Plant, which operated between 1960 and 2010 (Stinson 1984, Duke Energy South Bay 2004, Eguchi et al. 2010, Benson \& Dutton 2012, Turner-Tomaszewicz \& Seminoff 2012; Fig. 1). The power plant used once-through cooling (OTC) technology, drawing water from SDB through an intake channel to cool its 4 fossil-fuel generators and discharging warm water into an adjacent effluent channel. Green turtles habitually visited this effluent channel during colder months, concurrent with a decrease in water temperatures in the more northern portions of SDB (Stinson 1984, McDonald et al. 1994). A previous study indicated that a core activity area ( $50 \%$ utilization distribution [UD]) of green turtles in south SDB during 2009 to 2011 coincided with eel- 


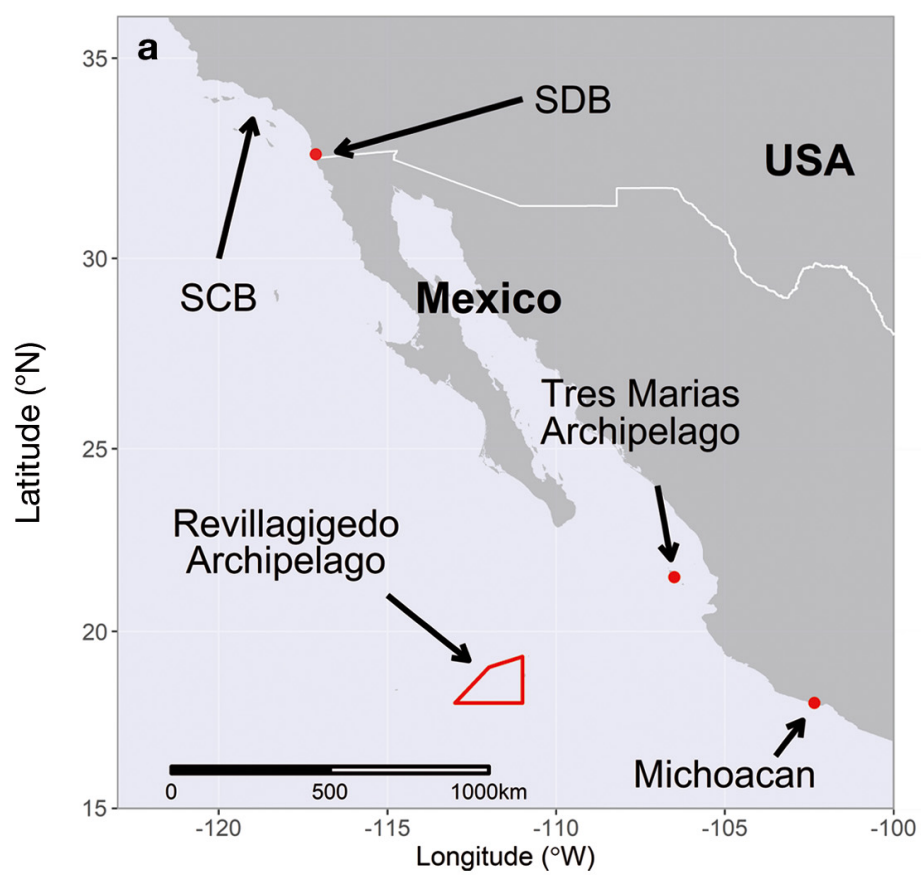

Fig. 1. (a) Study site (SDB) relative to 3 nesting rookeries for east Pacific green turtles Chelonia mydas in the southern California region. Vegetation (eelgrass) distributions within San Diego Bay in (b) 2008 (pre-) and (c) 2014 (postdecommissioning) are shown in green. The black box indicates the southern portion of the bay, which is shown in the subsequent plots. The orange star indicates the location of the power plant prior to closure, yellow and red solid arrows indicate intake and effluent channels, respectively. SCB: Southern California Bight
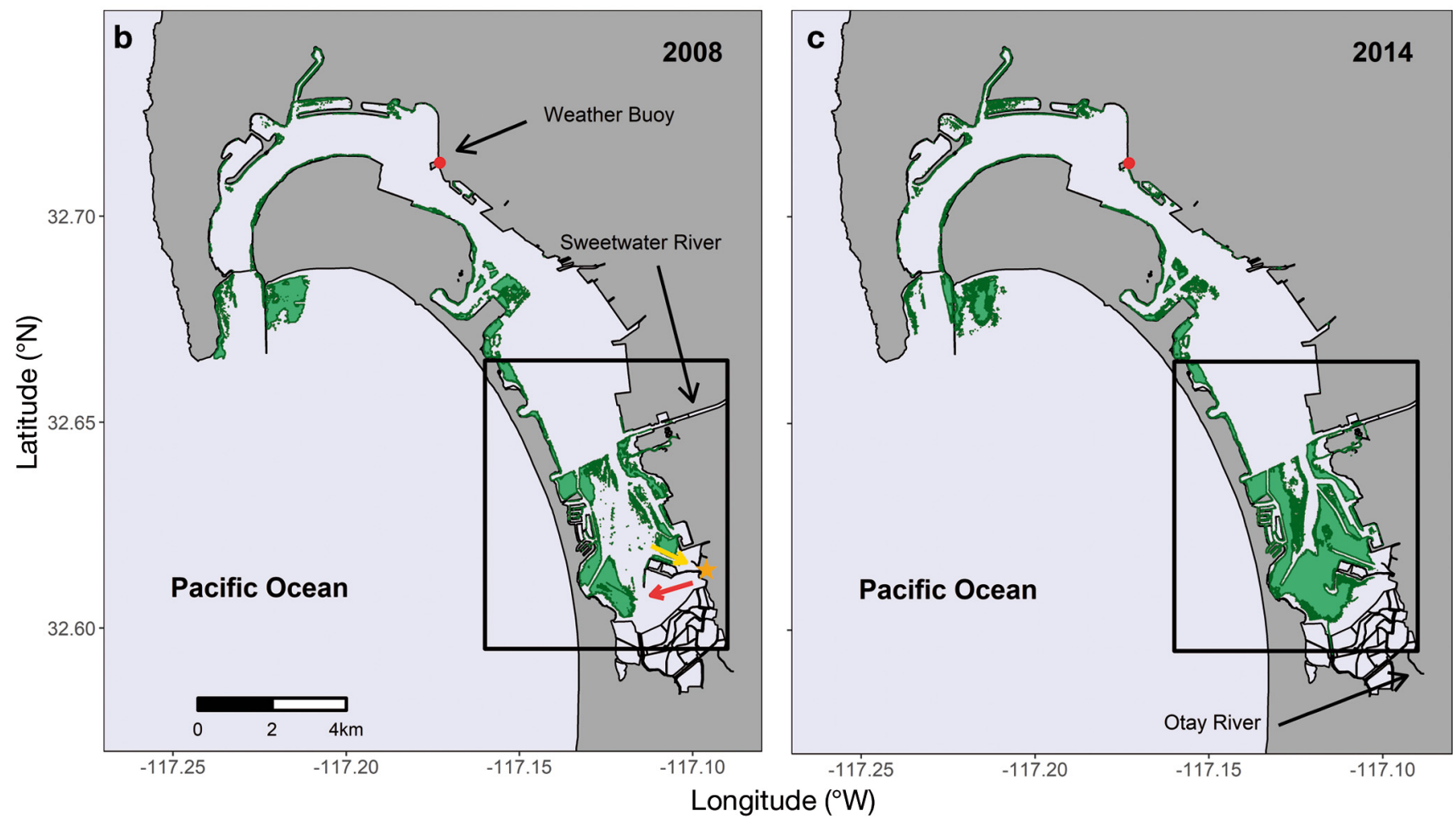

grass distributions and the effluent from the power plant (MacDonald et al. 2012). Due to the availability of year-round warm water, combined with an invertebrate-based diet, green turtles in SDB have shown fast somatic growth rates while the power plant was in operation (Lemons et al. 2011, Eguchi et al. 2012). However, since the power plant was decommissioned in 2010, the thermal environment in the south SDB has reverted to its natural thermal state. Turtles, especially small individuals, were associated with pockets of warm water, including areas distant to the power plant site, during winter months after the decommissioning of the power plant (Madrak et al. 2016). The long-term effects of this change in the thermal environment on turtles are yet to be determined. 
A study of green turtle home range was conducted when the power plant was still in operation, albeit at a reduced capacity (MacDonald et al. 2012). However, it was reasonable to expect that the change in the environment since 2010 has affected the behavior and/or habitat use of green turtles within SDB. In this study, we used GPS-enabled satellite transmitters to monitor movements of green turtles in SDB to understand changes in their movement patterns as results of the power plant closure. The thermal environment in the south part of SDB has reverted to its natural state since the power plant was decommissioned. We expected to see expansion of turtles' spatial distributions. The findings of this study are indicative of what to expect in the near future at many coastal sites where fossil-fuel power plants will be decommissioned and replaced with newer technologies that may affect the environment differently.

\section{MATERIALS AND METHODS}

In this study, we estimated the change in home ranges of green turtles in SDB before and after the power plant closure in 2010 through GPS-based telemetry. We define the pre-decommissioning telemetry period to be 2007 to 2010 and the post period to be 2011 to 2016 and refer them to as preand post-periods, respectively.

\subsection{Study site}

The northern-most foraging areas of east Pacific green turtles can be found along the West Coast of the USA, where at least 2 long-term foraging grounds have been identified: San Diego Bay (SDB) and areas near Long Beach, California (approximate latitudes of $32.5^{\circ}$ and $33.7^{\circ} \mathrm{N}$, respectively; Stinson 1984, Eguchi et al. 2010, Crear et al. 2016). SDB is the largest embayment in the Southern California Bight and found within a large metropolitan area. Two rivers (Otay and Sweetwater) provide freshwater inputs to the south SDB (Fig. 1). Aside from the dredged shipping channels in the northern part of the bay, most of the bay is $<15 \mathrm{~m}$ below mean lower low water (MLLW) and it is $<4.6 \mathrm{~m}$ below MLLW on average in the southern portion of the bay (Lambert \& Lambert 2003, Merkel \& Associates 2014). The bay contains one of the largest ports along the west coast of the USA and it is home to the Pacific Fleet of the U.S. Navy. Consequently, a significant amount of vessel traffic is present in the bay. The vast majority of military and industrial activities, as well as significant recreational boating, take place in the central and northern sections of the bay. The northern and central areas feature deep shipping channels and docks/marina that are close to the mouth of SDB (Fig. 1), whereas boat traffic in the southern section of the bay is primarily restricted to recreational boaters, kayakers, and fishers. The south portion of SDB is designated as a wildlife refuge to protect and manage habitat and wildlife (U.S. Fish and Wildlife Service 2006). Due to the shallowness of the southern section of the bay, where the water depths can be $<1 \mathrm{~m}$ at low tides, few boats visit the area and extensive vegetative habitat, where the most abundant species is eelgrass Zostera marina, is available (Merkel \& Associates 2014). Eelgrass, an important food source for green turtles (Lemons et al. 2011), has increased in coverage from 431 ha in 2008 to $>790$ ha in 2014 (Fig. 1, Merkel \& Associates 2009, 2014), perhaps owing to the power plant closure. Eelgrass distributions in SDB in 2008 and 2014 (Merkel \& Associates 2009, 2014) were treated as representative of the pre- and post-periods, respectively.

As part of long-term monitoring of green turtles in SDB since the 1970s, turtles were caught with entanglement nets (50-100 m length $\times 8 \mathrm{~m}$ depth, mesh size $=40 \mathrm{~cm}$ knot-to-knot). The entanglement nets used in this study have been used to capture the smallest of post-pelagic juvenile turtles at other green turtle foraging areas in Mexico (SCL $\geq 35 \mathrm{~cm}$; Seminoff et al. 2002) as well as in SDB (SCL $\geq 44.0 \mathrm{~cm}$; Eguchi et al. 2010). We therefore assumed that all size classes of green turtles in SDB would be caught by these nets. Due to the aforementioned vessel traffic within the northern part of SDB, capture nets were deployed only within the southern section. Exact locations of nets were dictated by tidal height, which restricted access to some areas during low tide. All nets were deployed from Boston Whalers (4 and $5.5 \mathrm{~m}$ in length) with outboard motors (25 and $75 \mathrm{hp}$, respectively). The distance of the nets from the shore ranged from approximately 10 to $100 \mathrm{~m}$, whereas water depths ranged from $<1$ to $6 \mathrm{~m}$. Nets were checked for turtles and other species at intervals of $\leq 30 \mathrm{~min}$. Captured turtles were transported to shore for measuring, weighing, and tagging. Straight carapace length (SCL) was measured from the nuchal notch to the posterior-most portion of the rear marginal scutes using a forester's caliper. Captured turtles were kept on land under a shade structure and closely monitored for their behavior. Body surfaces were kept moist to avoid overheating. 


\subsection{Satellite telemetry}

From 2007 to 2016, Fastloc-GPS satellite transmitters (GPS tags hereafter, Wildlife Computers, Mk10) were used to monitor short-term and fine-scale movements of green turtles within SDB. Transmitters were placed either within $5 \mathrm{~cm}$ of the nuchal notch or $1 / 4$ of the way back from the carapace as per Jones et al. (2011) with quick-setting epoxy (Power's Powerfast, Powers T150, or Sika Anchorfast). The placement of GPS tags minimized the hydrodynamic drag and maximized transmissions as green turtles often spend little time at the water surface and antennas had to be out of the water for successful transmission of data to ARGOS satellites (Jones et al. 2011).

Location data were received through ARGOS and processed with Wildlife Computers' software. We used only GPS-based relocation data with residual values $<35.0$ for computing home ranges (Dujon et al. 2014). Relocation data that fell outside of the bay or on land as well as north of $32.66^{\circ} \mathrm{N}$ were removed. The northernmost boundary (i.e. $32.66^{\circ} \mathrm{N}$ ) was determined after examining all relocation data points and recognizing different behavior (a foray outside of SDB) of a tagged turtle north of the boundary. The remaining data were grouped into six $4 \mathrm{~h}$ periods (00:00-03:59, 04:00-07:59, 08:00-11:59, 12:00-15:59, 16:00-19:59, and 20:00-23:59 h), and the best location (smallest residual) within each period was extracted.

\subsection{Utilization distributions (home ranges)}

Turtles with $<50$ filtered relocation points were excluded from estimation of utilization distributions (UDs) following the recommendation by Seaman et al. (1999). UDs were estimated using fixed kernel density methods (Worton 1989) with the adeHabitatHR package (Calenge 2006) in $\mathrm{R}$ (v. 3.6.1, R Development Core Team 2019). The best bandwidth of the kernel density estimation was determined via the ad hoc method (Kie 2013). In this method, the reference bandwidth $\left(h_{\text {ref }}\right)$ was multiplied by a fraction $(\alpha)$, from 0.95 with decrements of 0.05 , until the estimated $95 \%$ UD became non-contiguous. The smallest $\alpha$ with a contiguous $95 \%$ UD $\left(\alpha_{\text {best }}\right)$ was used to compute the best bandwidth ( $\left.h=\alpha_{\text {best }} \times h_{\text {ref }}\right)$ for UD estimation. The number of grid cells between the minimum and maximum extent was selected to eliminate sharp edges of UDs, where it was set at 1000. UDs were computed for all individuals combined for each period and for each individual separately. After UDs were computed, UD areas that overlapped with land were eliminated. Overlaps between UDs and eelgrass distributions were determined using the gIntersection function in the rGeos package (v. 0.5-2, Bivand \& Rundel 2019).

Because of the difference in sample sizes between the pre- and post-periods ( $n_{\text {pre }}$ and $\left.n_{\text {post }}\right)$, we investigated effects of sample size on estimated UDs. UDs were computed with all possible combinations of individuals of different sample size $\left(n_{\text {pre }}\right.$ to $\left.n_{\text {post }}-1\right)$ using the post-period dataset. For each randomly selected dataset, an appropriate bandwidth was determined using the ad hoc method described previously. Distributions of estimated UDs with various sample sizes were compared to the UD from all individuals in the post-period to determine the number of samples required to approximate the UD computed from $n_{\text {post }}$ individuals. To reduce the computational time, we did not remove land areas in this analysis. This did not affect the results because approximately equal amounts of land should have been part of estimated UDs in all cases.

The difference in UDs between pre- and postperiods was determined via a randomization method that taken into account the different sample sizes between the 2 periods. Similar to the aforementioned sample size investigation, all possible combinations of $n_{\text {pre }}$ individuals were selected randomly without replacement from the post-period and UDs estimated. The differences between the observed preperiod UD and the UDs from the post-period with $n_{\text {pre }}$ were used to create a distribution of differences. If there was no difference in UDs between the pre- and post-periods, the majority of the differences would distribute around zero. Positive or negative departure from zero would indicate a directional change in UDs between the 2 periods. Similar to the sample size determination analysis, we did not remove the land area to minimize the computational time.

To evaluate possible changes in behavior of turtles between day and night, UDs were also estimated for daytime and nighttime separately. Daytime was defined as a period between local sunrise and sunset, and nighttime as a period between local sunset and sunrise. Local sunset and sunrise time were determined via the sunrise.set function in the StreamMetabolism package (Sefick 2016) in R.

Variability of UDs among individuals and potential effects of environmental variables (e.g. water temperature, body size, and power plant operation) were investigated using general linear models. We considered ambient water temperatures that were unaffected by the power plant in SDB (average and stan- 
dard deviation at the middle of tag deployment), deployment periods (pre or post), the number of tracking days, and body mass $(\mathrm{kg})$ at the time of capture. Hourly water temperature at the weather buoy within SDB $\left(32.713^{\circ} \mathrm{N}, 117.173^{\circ} \mathrm{W}\right.$; Fig. 1) was obtained from the NOAA data portal (https://upwell.pfeg.noaa.gov) using a purpose-built $\mathrm{R}$ function (available from the first author upon request). Using subsets of the potential covariates that might have affected UD sizes, 8 models were fitted to observed data. The corrected AIC values for small sample sizes (Sugiura 1978) were used to select the most parsimonious model.

\section{RESULTS}

A total of 30 green turtles (15 putative females, 4 males, and 11 putative juveniles) were outfitted with GPS tags between 2007 and 2016; 7 were deployed during the pre-period and 23 during the post-period. The mean SCL of the 30 turtles was $87.8 \mathrm{~cm}$ (SE: 2.9 $\mathrm{cm}$ ) and ranged from 51.9 to $109.3 \mathrm{~cm}$. The mean body mass was $105.2 \mathrm{~kg}$ (SE: $9.4 \mathrm{~kg}$ ) and ranged from 19 to $241 \mathrm{~kg}$. The number of transmission days per individual ranged from 6.5 to $103.3 \mathrm{~d}$ (mean $\pm \mathrm{SE}$ : $43.5 \pm 5.0$ ). No statistical difference was found in SCL, body mass, or the number of transmission days between the 2 periods (results not shown).
The proportion of accepted relocations based on our filtering algorithm (residual values $<35.0$ and eliminating obvious erroneous locations) varied widely among individuals, ranging from 10 to $100 \%$, where $77 \%$ of all relocation points were accepted. A total of 13 turtles ( 3 pre- and 10 post-period) did not have sufficient relocation data to be used for estimating UDs. For day- and night-specific UD estimation, an additional 10 turtles (1 pre- and 9 post-period) were excluded due to insufficient relocation data (Table 1).

Subsampling the post-period data indicated that the mean of $71550 \%$ UDs from 4 randomly selected individuals ranged from 0.45 to $2.27 \mathrm{~km}^{2}$ (mean $\pm \mathrm{SE}$ : $1.29 \pm 0.34$; Fig. 2). The $50 \%$ UD estimated from all 13 individuals $\left(1.37 \mathrm{~km}^{2}\right)$ was within 1 standard deviation from the mean, albeit a large variability among estimates (Fig. 2). This result indicated that $\mathrm{n}=4$ during the pre-period was sufficient to estimate $50 \%$ UD even though it would have been better if a larger number of individuals were available.

Core activity area (50\% UD) almost doubled (from 0.71 to $1.37 \mathrm{~km}^{2}$ ) after the power plant was decommissioned. The increase was also seen in the randomization test in which 687 of 715 differences were greater than zero (Fig. 3). When the change in $50 \%$ UD was compared between day and night, a greater increase was found for the nighttime, where

Table 1. Capture date (mm/dd/yyyy), sex (U: undetermined), body mass, length (SCL: standard carapace length), the number of relocation points, and utilization distribution (UD) areas $\left(\mathrm{km}^{2}\right)$ of green turtles Chelonia mydas tagged with GPS-enabled satellite transmitters in San Diego Bay with sufficient relocation data to estimate UDs. Shaded rows indicate those tagged prior to the power plant closure. - indicates UDs were not estimated due to insufficient relocation data. Some measurements were from different dates $\left({ }^{*}=23 \mathrm{Jan} 2007,{ }^{+}=26\right.$ Feb 2009, ${ }^{\wedge}=8$ Mar 2011)

\begin{tabular}{|c|c|c|c|c|c|c|c|c|c|c|c|}
\hline \multirow{3}{*}{ ID } & \multirow{3}{*}{ Capture date } & \multirow{3}{*}{ Sex } & \multirow{3}{*}{$\begin{array}{l}\text { Mass } \\
(\mathrm{kg})\end{array}$} & \multirow{3}{*}{$\begin{array}{l}\mathrm{SCL} \\
(\mathrm{cm})\end{array}$} & \multirow{3}{*}{$\begin{array}{l}\text { No. of } \\
\text { relocations }\end{array}$} & \multirow{3}{*}{$50 \%$} & \multirow{3}{*}{$95 \%$} & \multirow{2}{*}{\multicolumn{2}{|c|}{$\begin{array}{l}\text { - UD- } \\
\text { Day }\end{array}$}} & \multirow{2}{*}{\multicolumn{2}{|c|}{ Night }} \\
\hline & & & & & & & & & & & \\
\hline & & & & & & & & $50 \%$ & $95 \%$ & $50 \%$ & $95 \%$ \\
\hline 52675 & $3 / 7 / 2007$ & $\mathrm{~F}$ & $241^{*}$ & $104.2^{*}$ & 146 & 1.24 & 6.87 & - & - & 0.51 & 2.62 \\
\hline 37623 & $5 / 23 / 2007$ & $\mathrm{~F}$ & 136 & 90 & 160 & 0.95 & 4.98 & 0.66 & 4.04 & 0.21 & 1.25 \\
\hline 44366 & $3 / 25 / 2009$ & $\mathrm{~F}$ & 97 & $92.4^{+}$ & 283 & 0.69 & 3.31 & 1.17 & 4.84 & 0.38 & 2.63 \\
\hline 78500 & $11 / 5 / 2009$ & $\mathrm{~F}$ & 121 & 100.4 & 159 & 0.31 & 3.53 & 0.65 & 3.63 & 0.47 & 4.00 \\
\hline 44359 & $5 / 25 / 2011$ & $\mathrm{U}$ & 63 & 74.6 & 125 & 0.60 & 3.76 & 2.20 & 7.57 & 0.45 & 2.69 \\
\hline 126065 & $6 / 4 / 2013$ & $\mathrm{~F}$ & $112^{\wedge}$ & 100.5 & 71 & 1.81 & 6.20 & - & - & - & - \\
\hline 126070 & $3 / 13 / 2014$ & $\mathrm{~F}$ & 176 & 109.3 & 182 & 1.35 & 5.01 & 1.61 & 5.50 & 0.92 & 3.94 \\
\hline 12606905 & $5 / 13 / 2014$ & $\mathrm{~F}$ & 121 & 95 & 130 & 1.12 & 4.57 & 1.51 & 5.56 & 0.96 & 5.11 \\
\hline 12607106 & $6 / 26 / 2014$ & $\mathrm{~F}$ & 150 & 100.8 & 68 & 0.46 & 2.80 & - & - & - & - \\
\hline 126068 & $7 / 1 / 2014$ & $\mathrm{~F}$ & 133 & 99 & 116 & 0.79 & 3.70 & 0.97 & 3.66 & 0.89 & 4.37 \\
\hline 151381 & $8 / 27 / 2015$ & $\mathrm{U}$ & 66 & 75.2 & 66 & 0.58 & 2.53 & - & - & - & - \\
\hline 151375 & $8 / 27 / 2015$ & $\mathrm{~F}$ & 152 & 102.5 & 70 & 1.25 & 4.32 & - & - & - & - \\
\hline 152323 & 12/8/2015 & $\mathrm{F}$ & 127 & 94.8 & 139 & 0.69 & 6.01 & - & - & - & - \\
\hline 152314 & $12 / 15 / 2015$ & $\mathrm{~F}$ & 137 & 101 & 185 & 0.53 & 5.30 & - & - & - & - \\
\hline 152319 & 6/15/2016 & $\mathrm{U}$ & 33 & 62.3 & 89 & 1.77 & 5.71 & - & - & - & - \\
\hline 151384 & $6 / 29 / 2016$ & $\mathrm{U}$ & 38 & 65.4 & 81 & 1.46 & 6.02 & - & - & - & - \\
\hline 152315 & $6 / 29 / 2016$ & $\mathrm{U}$ & 52 & 71 & 161 & 1.25 & 5.39 & - & - & - & - \\
\hline
\end{tabular}




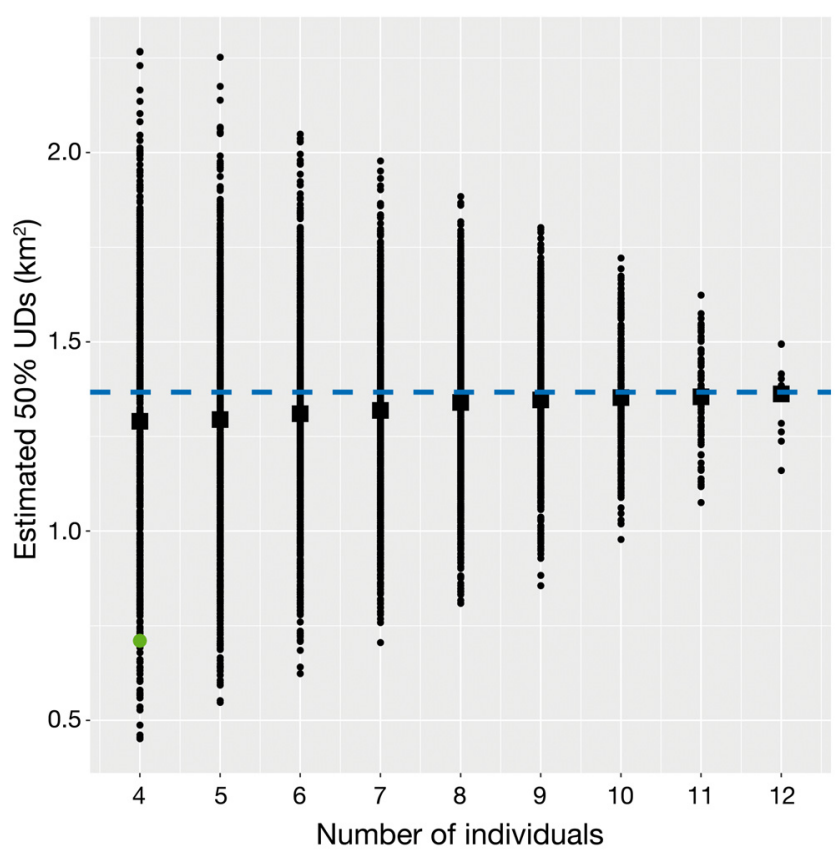

Fig. 2. Effects of sample sizes (number of individuals) on estimated $50 \%$ UDs for the post period. Squares: mean of estimated UDs for a given sample size; blue dashed line: the estimated 50\% UDs using all individuals $(\mathrm{n}=13)$; green dot: the estimated $50 \%$ UD for the pre-period

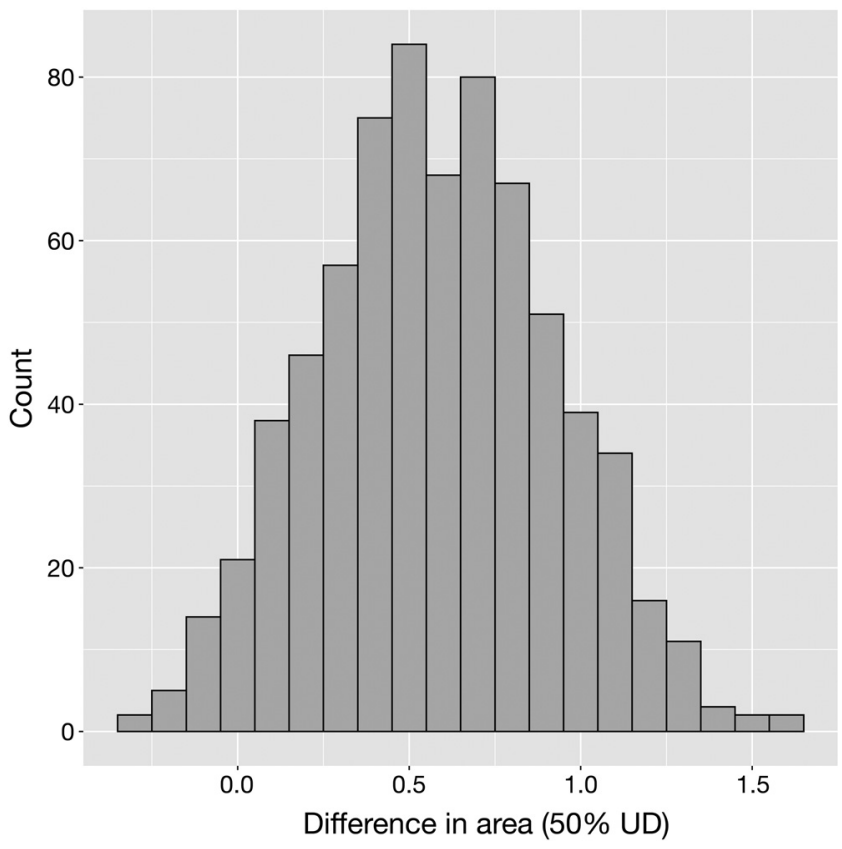

Fig. 3. Differences in estimated 50\% UDs between the preperiod and 715 randomly selected $n_{\text {pre }}=4$ individuals without replacement from the post-period, where 687 differences were $>0$ it increased from 0.52 to $1.44 \mathrm{~km}^{2}$, whereas the daytime change was less (from 1.32 to $1.43 \mathrm{~km}^{2}$; Fig. 4). During the pre-period, the overlap between daytime and nighttime $50 \%$ UDs was $0.37 \mathrm{~km}^{2}$ (28\% of the daytime $50 \%$ UD), whereas it was $0.67 \mathrm{~km}^{2}$ (47\% of the daytime $50 \%$ UD) during the post-period.

Changes in core activity areas (50\% UD) between pre- and post-periods were also seen in their locations. During the pre-period, $50 \%$ UDs were found south of the jetty that separated the intake (north) and effluent (south) flows; apparently, turtles were using the warm effluent. After the power plant closure, however, turtles were found in the water adjacent to the north of the jetty, which is closer to a large

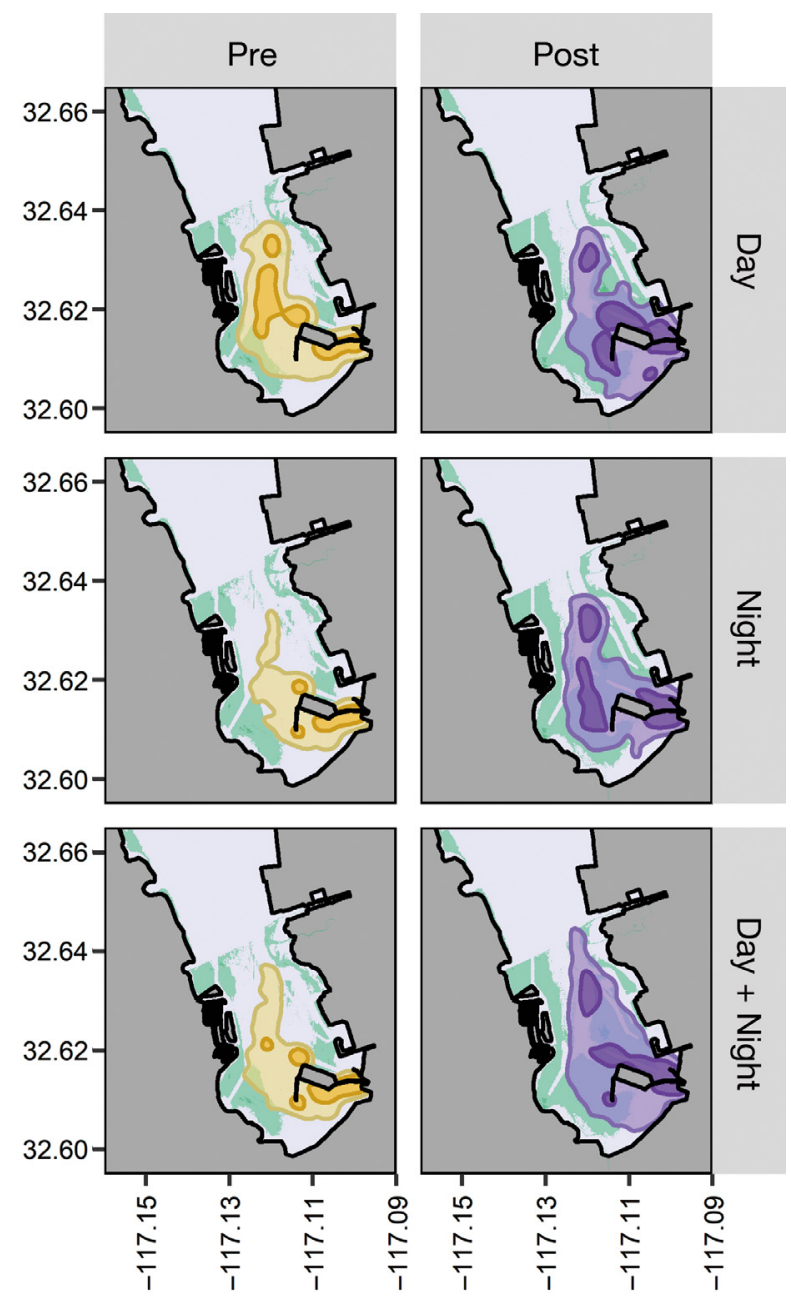

Fig. 4. Estimated home ranges of green turtles in San Diego Bay, with UDs for the pre-period (left panel) and post-period (right panel). Top row is the daytime (sunrise to sunset), second row is the nighttime (sunset to sunrise), and the third row is daytime and nighttime combined. Light and dark color indicate $95 \%$ and $50 \%$ UDs, respectively. Vegetative habitat in 2008 and 2014 is indicated in green for pre- and post-period, respectively 
eelgrass pasture than the south of the jetty (Figs. 1 \& 4). During the pre-period, the core activity area during nighttime was mostly restricted to the effluent channel, whereas the core activity area during daytime included northwest of the effluent channel. During the post-period, however, the core activity areas during nighttime and daytime were similar (Fig. 4).

The apparent expansion of turtles' home ranges and vegetative habitat within SDB resulted in an increase in the overlap between the two. Vegetative habitat in south SDB increased from $2.83 \mathrm{~km}^{2}$ in 2008 to $5.70 \mathrm{~km}^{2}$ in 2014 . Combined with the aforementioned increase in UDs, the overlap between estimated $50 \%$ UD and vegetative habitat was $273 \mathrm{~m}^{2}$ during the pre-period. The overlap increased to $0.43 \mathrm{~km}^{2}$ during the post-period. During the nighttime, there was virtually no overlap in the pre-period $\left(15.3 \mathrm{~m}^{2}\right)$ but it was $0.50 \mathrm{~km}^{2}$ in the post-period. During the daytime, the overlap increased from 0.02 to $0.36 \mathrm{~km}^{2}$. Among the 8 linear models fitted to individual $50 \%$ UDs of green turtles in SDB, the most parsimonious model (Table A1 in the Appendix) included the intercept and the standard deviation of water temperature at the middle of tag deployment $\left(\mathrm{r}^{2}=\right.$ 0.37 , slope $=2.1 \pm 0.64$ ). Although the model only explained $37 \%$ of the variability in $50 \%$ UDs, the estimated positive slope indicated that a greater variability in water temperature in the middle of tag deployment resulted in larger UDs.

\section{DISCUSSION}

The recovering east Pacific green turtle population will likely result in more turtles entering the nearshore neritic habitat along the southern California coast in the future. They have been increasingly observed in estuaries and embayments along the southern California coast in recent years (NOAA unpubl. data). Because of the dense human population along this coastline, interactions between humans and green turtles are inevitable. In this study, we investigated the effects of human activity, namely a power plant closure, on green turtle home ranges using GPS-based telemetry. The resulting data shed light on how home range of turtles and human activities might overlap. This information is essential for developing effective management plans.

GPS-based telemetry provides fine-scale animal movement data that are not available from other methods, such as radio, ultrasonic and ARGOS-based satellite telemetry (White \& Sjöberg 2002, Heupel et al. 2006, Thomson et al. 2017), albeit at increased cost (Schofield et al. 2007, Dujon et al. 2014). Studies have indicated GPS-based telemetry is useful for elucidating habitat use and movements of wild animals in marine and terrestrial environments (Owen-Smith \& Goodall 2014, Christiansen et al. 2017). We found that even with GPS-based telemetry, however, some data points were obviously inaccurate, e.g. found on land. These findings are a reminder that high precision of every data point from GPS telemetry should not be assumed. Measures of accuracy and precision, such as residual values, and visual inspection should be used to filter erroneous data points (e.g. Hazel et al. 2009, Shimada et al. 2012). Nevertheless, with proper handling of received location data, GPS telemetry provides detailed information of animal habitat use and home range that is difficult to obtain otherwise (Dujon et al. 2014, Thomson et al. 2017, Christiansen et al. 2017, Dujon et al. 2018).

Home ranges of green turtles are affected by environmental factors such as patchiness of prey and water temperature. We found large variability in core activity areas (50\% UDs) among individuals, which were positively correlated with the variability of water temperature at the middle of the tag deployment. It is possible that a large difference in temperature within a short time period at the middle of telemetry might affect the change in their behavior, resulting in larger estimated home ranges over the entire telemetry period.

Green turtles at other foraging grounds have also shown a wide range of UDs. For example, immature east Pacific green turtles (50.9 to $77.6 \mathrm{~cm} \mathrm{SCL}, \mathrm{n}=12$ ) in Bahia de Los Angeles in the Gulf of California, Mexico, used 4 to $32 \mathrm{~km}^{2}$ as their home ranges, as determined via radio and acoustic telemetry (Seminoff et al. 2002). For another example, home ranges of immature green turtles (27.9 to $48.1 \mathrm{~cm} \mathrm{SCL}, \mathrm{n}=6$ ) in southeast Florida, USA, determined via acoustic telemetry, ranged from 0.7 to $4.9 \mathrm{~km}^{2}$ (Makowski et al. 2006); these turtles in Florida spent most of their time over shallow worm-rock reef tract. Another study, using radio telemetry, on the east coast of Australia indicated home ranges of adult green turtles to be 0.8 to $8.5 \mathrm{~km}^{2}$ ( $\mathrm{n}=10$; Whiting \& Miller 1998), whereas a recent study with the GPS technology reported home ranges of green turtles in the same region to be 0.1 to $3.6 \mathrm{~km}^{2}$ ( $\mathrm{n}=6 ; 5.1 \mathrm{~km}^{2}$ combined; Gredzens et al. 2014). Regardless of how data were collected, estimated home ranges in our study were similar to those from Florida and eastern Australia but differ from Gulf of California. This result indicates that site fidelity and the spatial scale of local move- 
ments of foraging green turtles is variable among locations, likely caused by spatial distribution of their diet, predator distributions, and density of turtles. Large home ranges for the Bahia de Los Angeles aggregation might be a result of sparse prey resources in the area owing in part to commercial harvest of marine algae and the size of habitat, where the bay is larger and deeper than SDB (Seminoff et al. 2002).

While the power plant was in operation, there was a distinct diel pattern in movements of green turtles in south SDB (Fig. 4). The core activity area $(50 \%$ UD) was mostly restricted in the effluent channel during the nighttime. During the daytime, however, the core area extended to further north. This diel pattern disappeared during the post-period, where the difference between daytime and nighttime was not as apparent. This change was also found in the overlap of UDs between daytime and nighttime from the pre- and post-period ( $28 \%$ to $47 \%$ of daytime UDs). The observed difference between the pre- and postperiods might have been the result of the change in the thermal environment due to the power plant closure, increased vegetative habitat in the area, or a combination of these factors. Green turtles at the Chagos Archipelago used smaller home ranges during the nighttime than daytime (Christiansen et al. 2017). The observed difference was attributed to potential predation risks and physical factors, such as depth, tides, and currents. In SDB, there are no natural predators of green turtles. To elucidate drivers of the core activity areas in SDB, longer deployments of more GPS-enabled satellite tags and monitoring of the environment, such as annual distributions of vegetation, are necessary.

Examinations of the home ranges of green turtles in SDB indicated that core activity areas often did not overlap with vegetative habitat, whereas their known resting area, i.e. the effluent channel during the pre-period, was determined as a core use area (Fig. 4). This might have been an artifact of data transmissions through satellites. While foraging, turtles might not spend sufficient time at the water surface for the GPS tag to acquire and transmit its location. While transiting or resting, on the other hand, the antenna might break the water surface for longer periods of time, allowing more transmissions to be made. To test such hypothesis, however, behavior of GPS-tagged turtles must be recorded. Nonetheless, the overlap between vegetative habitat and core use areas increased from the pre- to post-period.

In SDB, green turtles are known to forage on eelgrass as well as various invertebrate species (Lemons et al. 2011). Vegetation in the south bay expanded during the study period (from $2.83 \mathrm{~km}^{2}$ in 2008 to $5.70 \mathrm{~km}^{2}$ in 2014), likely a consequence of the power plant closure. The observed expansion, however, may be ephemeral because eelgrass distributions in SDB are negatively affected by warm waters caused by oceanographic events, such as El Niño Southern Oscillation (Johnson et al. 2003, Echavarria-Heras et al. 2006). The severity of eelgrass wasting disease, caused by the marine pathogen Labyrinthula zosterae, increases with temperature and nutrient enrichment (Dawkins et al. 2018, Hughes et al. 2018). As ocean warming continues and more nutrients are introduced to SDB from human activities in surrounding cities, it is possible that eelgrass pastures in SDB may shrink in the future, which may result in a wider distribution of green turtles in the bay and perhaps larger home ranges. In fact, surveys in the recent years have indicated the eelgrass distributions in SDB and other southern California estuaries are shrinking in some areas (NOAA unpubl. data).

A previous acoustic telemetry study in SDB indicated that the power plant closure had a significant effect on movements of green turtles, particularly in the winter period (Madrak et al. 2016). They found that the turtles in SDB were associated with warmer water in the winter months and that smaller turtles were found in warmer water than larger turtles, perhaps a result of their lesser thermal inertia due to differences in body size/surface area ratio. These findings suggested that turtles were using the effluent from the power plant as a thermal refuge during cold months (Madrak et al. 2016). In other words, the heated effluent from the power plant attracted turtles to the south part of SDB, especially in winter. We also found core use areas in the effluent area during the pre-period. The strong affinity of green turtles to artificial warm waters has been reported for green turtles inhabiting waters adjacent to OTC power plants in the San Gabriel River, CA, $120 \mathrm{~km}$ to the north of SDB (Crear et al. 2016, 2017). These power plants also are planned to be decommissioned in the near future (California Energy Commission 2019), which will possibly result in changes in habitat use by local green turtles.

After the decommissioning of the power plant, however, green turtles have since shifted their core activities to the old intake channel instead of the old effluent channel (Fig. 4). The effluent channel also became shallow after the constant water flow stopped with the power plant closure, as the scouring action of effluent was no longer present and siltation increased. It is possible that turtles moved to the northern part of the jetty after the power plant clo- 
sure for these reasons. Recaptures of the same turtles in the old intake and effluent channels over the years indicated that these are not different turtles using different habitat (NOAA unpubl. data). We note, however, turtles have been observed in the old effluent channel in the recent years, indicating they still use the same area. The ambient water temperatures during winter months are expected to be highest at the southern end of the bay where water depths are the shallowest and effects of solar heating may be substantial. Consequently, it is reasonable to presume that turtles will be mostly aggregated in the southern portion of the bay during winter months. When the water is warm during summer and fall, we expect distributions of turtles in the bay to be correlated with eelgrass habitat.

The decommissioning of the power plant in SDB eliminated a thermal refuge of green turtles during cold months. The year-round artificially warm environment caused by the OTC power plant in SDB had an unintended consequence for the foraging aggregation of green turtles. The somatic growth rates of these turtles were among the fastest reported for the species, presumably due to the ability of the turtles to be active and forage throughout the year (Eguchi et al. 2012). Although unquantified, the increased growth rates probably resulted in faster sexual maturation than in the natural environment. Somatic growth rates of these turtles will likely to slow down, removing an anthropogenic effect on the turtles.

Because the entire bay is surrounded by urbanized environment, the foraging aggregation is impacted by human activities even without the OTC power plant. Negative anthropogenic impacts on turtles include boat strikes and exposure to organic and inorganic toxins (Komoroske et al. 2012, Barraza et al. 2019), although the latter may be sub-lethal. During the last several years, the number of stranded green turtles with evidence of boat collisions has increased within SDB and surrounding areas (NOAA unpubl. data). Although some of these collisions could have happened postmortem, this observed increase in interactions between boats and turtles may be attributed to the increasing abundance and, possibly, expanding home ranges of turtles. Collisions between sea turtles and boats have been reported at foraging grounds and near nesting beaches around the globe (reviewed by Denkinger et al. 2013).

As the east Pacific green turtle population increases (Seminoff et al. 2015), it is expected that more turtles will be entering the nearshore environment along the coast of southern California, where large cities exist. Reducing anthropogenic deaths of green turtles in
SDB, including ingestion and entanglement in discarded fishing gear and boat collisions, requires a holistic approach. Reducing boat speed would decrease the chance of collisions with turtles, as it has been shown to be effective for reducing the collisions between manatees Trichechus manatus and boats (Calleson \& Frohlich 2007, Calleson 2014) and between North Atlantic right whales Eubalaena glacialis and large vessels (Conn \& Silber 2013). However, it is difficult to ensure recreational boaters reduce boat speed voluntarily in the nearshore lagoons and bays without strict regulations (Gorzelany 2004). Increased awareness of the presence of green turtles in the nearshore environment and the possibility of collisions with water crafts through education and signage may result in voluntary reduction of vessel speed by some boaters. Public outreach activities are part of ongoing effort by NOAA Fisheries and US Navy in southern California. Further, various stake holders, such as the city (port authority), state (water resource regulation), and federal (military and wildlife management) agencies need to communicate effectively and participate in management activities. Additionally, using the close association of eelgrass habitat and green turtle movements, managers may reduce eelgrass habitat in the northern part of the bay where the majority of boat traffic occurs and enhance eelgrass habitat within the southern part of the bay where boating activities are minimal. This has the potential to increase density of turtles in the southern part of the bay. It is important to note, however, that all green turtles in SDB have to pass through the northern part of SDB in order to enter or exit the bay. Consequently, the reduction of foraging habitat in the northern part of the bay will not eliminate the possibility of boat collisions with turtles.

\section{CONCLUSIONS}

As the results of this study show, seemingly innocuous and environmentally friendly actions by humans, such as shutting down a fossil-fuel power plant, can result in unintended negative impacts on a wildlife population (e.g. increasing the home range of a species into areas with increased human activity, leading to a potential increase in boat strikes). This study provides an example of how consequences of proposed human actions (e.g. construction of oil rigs, solar panel farms, and offshore windmills) are not easily foreseeable and therefore should be considered with a holistic understanding of the environment and wildlife species. Development of regula- 
tions (such as changes in boat speed limits) and conservation strategies (such as increasing awareness of turtle presence) must be based on knowledge from empirical studies. Those studies should focus on expanding basic understanding of demography, such as survival and emigration/immigration rates, and habitat use of population or aggregation of interest, such as has been accomplished for green turtles in San Diego Bay.

Acknowledgements. We thank Camryn Allen, Arthur Barraza, Christiana Boerger, Peter Dutton, Megan Hanna, Lisa Komoroske, Erin LaCasella, Garrett Lemons, Katie O'Laughlin, Ralph Pace, Jessica Priest, Dan Prosperi, Joel Schumacher, and Calandra Turner-Tomaszewicz for their help in the field. We also thank Eileen Maher of the Unified Port of San Diego for her support in the telemetry study. Tom Liebst at South Bay Power Plant (Dynergy) was always helpful during our field operations. Heidi Dewer and anonymous reviewers provided helpful comments to an earlier version of the manuscript. This study was conducted under the NMFS Research Permit \# 1591 and 16803. Turtle handling procedures were approved by the Southwest/Pacific Island Region Regional National Marine Fisheries Service Institutional Animal Care and Use Committee.

\section{LITERATURE CITED}

Barraza AD, Komoroske LM, Allen CD, Eguchi T and others (2019) Trace metals in green sea turtles (Chelonia mydas) inhabiting two southern California coastal estuaries. Chemosphere 223:342-350

* Becker E, Forney K, Fiedler P, Barlow J and others (2016) Moving towards dynamic ocean management: How well do modeled ocean products predict species distributions? Remote Sens 8:149

Benson SR, Dutton PH (2012) Sea turtles of the U.S. west coast. In: Seminoff JA, Wallace BP (eds) Sea turtles of the Eastern Pacific: advances in research and conservation. The University of Arizona Press, Tucson, AZ, p 88-110

Bivand R, Rundel C (2019). rgeos: interface to Geometry Engine - Open Source ('GEOS'). R package version 0.5-2. https://CRAN.R-project.org/package=rgeos

Bolten AB (2003) Variation in sea turtle life history patterns: neritic vs. oceanic developmental stages. In: Lutz PL, Musick JA, Wyneken J (eds) The biology of sea turtles, Vol 2. CRC Press, Boca Raton, FL, p 243-257

Broderick AC, Coyne MS, Fuller WJ, Glen F, Godley BJ (2007) Fidelity and over-wintering of sea turtles. Proc R Soc B 274:1533-1538

Calenge C (2006) The package adehabitat for the R software: a tool for the analysis of space and habitat use by animals. Ecol Modell 197:516-519

* California Energy Commission (2019) https://ww2.energy.ca. gov/sitingcases/alamitos/index.html (accessed 16 January 2020)

Calleson CS (2014) Issues and opportunities associated with using manatee mortality data to evaluate the effectiveness of manatee protection efforts in Florida. Endang Species Res 26:127-136

* Calleson CS, Frohlich RK (2007) Slower boat speeds reduce risks to manatees. Endang Species Res 3:295-304
Christiansen F, Esteban N, Mortimer JA, Dujon AM, Hays GC (2017) Diel and seasonal patterns in activity and home range size of green turtles on their foraging grounds revealed by extended Fastloc-GPS tracking. Mar Biol 164:10

Conn PB, Silber GK (2013) Vessel speed restrictions reduce risk of collision-related mortality for North Atlantic right whales. Ecosphere 4:43

* Crear DP, Lawson DD, Seminoff JA, Eguchi T, LeRoux RA, Lowe CG (2016) Seasonal shifts in the movement and distribution of green sea turtles Chelonia mydas in response to anthropogenically altered water temperatures. Mar Ecol Prog Ser 548:219-232

Crear DP, Lawson DD, Seminoff JA, Eguchi T, LeRoux RA, Lowe CG (2017) Habitat use and behavior of the east Pacific gren turtle, Chelonia mydas in an urbanized system. Bull South Calif Acad Sci 116:17-32

* Dawkins PD, Eisenlord ME, Yoshioka RM, Fiorenza E and others (2018) Environment, dosage, and pathogen isolate moderate virulence in eelgrass wasting disease. Dis Aquat Org 130:51-63

* Denkinger J, Parra M, Muñoz JP, Carrasco C and others (2013) Are boat strikes a threat to sea turtles in the Galapagos Marine Reserve? Ocean Coast Manage 80:29-35

* Dujon AM, Lindstrom RT, Hays GC (2014) The accuracy of Fastloc-GPS locations and implications for animal tracking. Methods Ecol Evol 5:1162-1169

* Dujon AM, Schofield G, Lester RE, Papafitsoros K, Hays GC (2018) Complex movement patterns by foraging loggerhead sea turtles outside the breeding season identified using Argos-linked Fastloc-Global Positioning System. Mar Ecol 39:e12489

Duke Energy South Bay (2004) SBPP Cooling water system effects on San Diego Bay. Vol 1: Compliance with Section 316(1) of the Clean Water Act for the South Bay Power Plant. Submitted to San Diego Regional Water Quality Control Board, San Diego, CA

* Dunn DC, Maxwell SM, Boustany AM, Halpin PN (2016) Dynamic ocean management increases the efficiency and efficacy of fisheries management. Proc Natl Acad Sci USA 113:668-673

* Dutton PH, LeRoux RA, LaCasella EL, Seminoff JA, Eguchi T, Dutton DL (2019) Genetic analysis and satellite tracking reveal origin of the green turtles in San Diego Bay. Mar Biol 166:3

Echavarria-Heras HA, Solana-Arellano E, Franco-Vizcaíno E (2006) The role of increased sea surface temperature on eelgrass leaf dynamics: onset of El Niño as a proxy for global climate change in San Quintín Bay, Baja California. Bull South Calif Acad Sci 105:113-127

*Eguchi T, Seminoff JA, LeRoux RA, Dutton PH, Dutton DL (2010) Abundance and survival rates of green turtles in an urban environment: coexistence of humans and an endangered species. Mar Biol 157:1869-1877

Eguchi T, Seminoff JA, LeRoux RA, Prosperi D, Dutton DL, Dutton PH (2012) Morphology and growth rates of the green sea turtle (Chelonia mydas) in a northern-most temperate foraging ground. Herpetologica 68:76-87

Eguchi T, Benson SR, Foley DG, Forney KA (2017) Predicting overlap between drift gillnet fishing and leatherback turtle habitat in the California Current Ecosystem. Fish Oceanogr 26:17-33

*Gorzelany JF (2004) Evaluation of boater compliance with manatee speed zones along the Gulf coast of Florida. Coast Manage 32:215-226

* Gredzens C, Marsh H, Fuentes MMPB, Limpus CJ, Shimada T, Hamann M (2014) Satellite tracking of sympatric mar- 
ine megafauna can inform the biological basis for species co-management. PLOS ONE 9:e98944

Halpern BS, Frazier M, Potapenko J, Casey KS and others (2015) Spatial and temporal changes in cumulative human impacts on the world's ocean. Nat Commun 6: 7615

Hazel J, Lawler IR, Hamann M (2009) Diving at the shallow end: green turtle behaviour in near-shore foraging habitat. J Exp Mar Biol Ecol 371:84-92

Heupel MR, Semmens JM, Hobday AJ (2006) Automated acoustic tracking of aquatic animals: scales, design and deployment of listening station arrays. Mar Freshw Res 57:1-13

Howell EA, Kobayashi DR, Parker DM, Balazs GH, Polovina JJ (2008) TurtleWatch: a tool to aid in the bycatch reduction of loggerhead turtles Caretta caretta in the Hawaiibased pelagic longline fishery. Endang Species Res 5: 267-278

Howell EA, Hoover A, Benson SR, Bailey H, Polovina JJ, Seminoff JA, Dutton PH (2015) Enhancing the TurtleWatch product for leatherback sea turtles, a dynamic habitat model for ecosystem-based management. Fish Oceanogr 24:57-68

*Hughes RG, Potouroglou M, Ziauddin Z, Nicholls JC (2018) Seagrass wasting disease: nitrate enrichment and exposure to a herbicide (Diuron) increases susceptibility of Zostera marina to infection. Mar Pollut Bull 134:94-98

Johnson MR, Williams SL, Lieberman CH, Solbak A (2003) Changes in the abundance of the seagrasses Zostera marina L. (eelgrass) and Ruppia maritima L. (widgeongrass) in San Diego, California, following an El Niño Event. Estuaries 26:106-115

Jones TT, Bostrom B, Carey M, Imlach B and others (2011) Determining transmitter drag and best-practice attachment procedures for sea turtle biotelemetry. NOAA Tech Memo NOAA-TM-NMFS-SWFSC-480. https://swfsc.noaa. gov/publications/TM/SWFSC/NOAA-TM-NMFSSWFSC-480.pdf (accessed 25 April 2019)

Kie JG (2013) A rule-based ad hoc method for selecting a bandwidth in kernel home-range analyses. Anim Biotelem 1:13

Komoroske LM, Lewison RL, Seminoff JA, Deustchman DD, Deheyn DD (2012) Trace metals in an urbanized estuarine sea turtle food web in San Diego Bay, CA. Sci Total Environ 417-418:108-116

Kamont MM, Fujisaki I, Stephens BS, Hackett C (2015) Home range and habitat use of juvenile green turtles (Chelonia mydas) in the northern Gulf of Mexico. Anim Biotelem 3:53

Lemons G, Lewison R, Komoroske L, Gaos A and others (2011) Trophic ecology of green sea turtles in a highly urbanized bay: insights from stable isotopes and mixing models. J Exp Mar Biol Ecol 405:25-32

Lewison R, Hobday AJ, Maxwell S, Hazen E and others (2015) Dynamic ocean management: identifying the critical ingredients of dynamic approaches to ocean resource management. Bioscience 65:486-498

Lambert CC, Lambert G (2003) Persistence and differential distribution of nonindigenous ascidians in harbors of the Southern California Bight. Mar Ecol Prog Ser 259:145-161

MacDonald B, Lewison R, Madrak S, Seminoff J, Eguchi T (2012) Home ranges of East Pacific green turtles Chelonia mydas in a highly urbanized temperate foraging ground. Mar Ecol Prog Ser 461:211-221

Madrak SV, Lewison RL, Seminoff JA, Eguchi T (2016) Characterizing response of East Pacific green turtles to changing temperatures: using acoustic telemetry in a highly urbanized environment. Anim Biotelem 4:22

Makowski C, Seminoff JA, Salmon M (2006) Home range and habitat use of juvenile Atlantic green turtles (Chelonia mydas L.) on shallow reef habitats in Palm Beach, Florida, USA. Mar Biol 148:1167-1179

Mann KH, Lazier JRN (1996) Dynamics of marine ecosystem. Blackwell Science, Cambridge, MA

* Maxwell SM, Hazen EL, Lewison RL, Dunn DC and others (2015) Dynamic ocean management: defining and conceptualizing real-time management of the ocean. Mar Policy 58:42-50

McDonald D, Dutton P, Mayer D, Merkel K (1994) Review of the green turtles of South San Diego Bay in relation to the operations of the SDG\&E South Bay Power Plant. Doc 94-045-01. Prepared for San Diego Gas \& Electric Co., C941210311. San Diego, CA

* Mendonça MT (1983) Movements and feeding ecology of immature green turtles (Chelonia mydas) in a Florida lagoon. Copeia 1983:1013-1023

Merkel and Associates (2009) 2008 San Diego Bay Eelgrass Inventory and Bathymetry Update. Prepared for US Navy Region Southwest Naval Facilities Engineering Command and San Diego Unified Port District. https:// pantheonstorage.blob.core.windows.net/environment/ 2008_San-Diego-Bay-Eelgrass-Inventory.pdf (accessed 25 April 2019)

Merkel and Associates (2014) 2014 San Diego Bay Eelgrass Inventory. Prepared for US Navy Region Southwest Naval Facilities Engineering Command and San Diego Unified Port District. https://www.westcoast.fisheries.noaa.gov/ publications/gis_maps/maps/eelgrass/2014-eelgrasssurvey-report.pdf (accessed 25 April 2019)

Musick JH, Limpus CJ 1997. Habitat utilization and migration in juvenile sea turtles. In: Lutz PL, Musick JA (eds) Biology of sea turtles, Vol 1. CRC Press, Boca Raton, FL, p 137-163

Owen-Smith N, Goodall V (2014) Coping with savanna seasonality: comparative daily activity patterns of African ungulates as revealed by GPS telemetry. J Zool (Lond) 293:181-191

Plotkin P (1996) Adult migrations and habitat use. In: Lutz PL, Musick JA, Wyneken J (eds) The biology of sea turtles, Vol 2. CRC Press, Boca Raton, FL, p 225-241

Pritchard PCH (1997) Evolution, phylogeny, and current status. In: Lutz PL, Musick JA (eds) The biology of sea turtles, Vol 1. CRC Press, Boca Raton, FL, p 1-28

R Development Core Team (2019) R: a language and environment for statistical computing. $\mathrm{R}$ Foundation for Statistical Computing, Vienna. https://www.R-project. org/

Renaud ML, Carpenter JA (1994) Movements and submergence patterns of loggerhead turtles (Caretta caretta) in the Gulf of Mexico determined through satellite telemetry. Bull Mar Sci 55:1-15

Ross PS, Barlow J, Jefferson TA, Hickie BE and others (2011) Ten guiding principles for the delineation of priority habitat for endangered small cetaceans. Mar Policy 35: 483-488

Salmon M (2006) Protecting sea turtles from artificial night lighting at Florida's oceanic beaches. In: Rich C, Longcore $\mathrm{T}$ (eds) Ecological consequences of artificial night lighting. Island Press, Washington, DC

* Schofield G, Bishop CM, MacLean G, Brown P and others (2007) Novel GPS tracking of sea turtles as a tool for conservation management. J Exp Mar Biol Ecol 347:58-68

* Schofield G, Hobson VJ, Fossette S, Lilley MKS, Katselidis KA, Hays GC (2010) Fidelity to foraging sites, consis- 
tency of migration routes and habitat modulation of home range by sea turtles. Divers Distrib 16:840-853

Seaman DE, Millspaugh JJ, Kernohan BJ, Brundige GC, Raedeke KJ, Gitzen RA (1999) Effects of sample size on kernel home range estimates. J Wildl Manag 63: 739-747

Sefick S Jr (2016). Stream metabolism-a package for calculating single station metabolism from diurnal oxygen curves. R package version 1.1.2. https://cran.r-project.org/ web/packages/StreamMetabolism/index.html (accessed 25 April 2019)

Seminoff JA, Resendiz A, Nichols WJ (2002) Home range of green turtles Chelonia mydas at a coastal foraging area in the Gulf of California, Mexico. Mar Ecol Prog Ser 242: 253-265

Seminoff JA, Allen CD, Balazs GH, Dutton PH and others (2015) Status review of the green turtle (Chelonia mydas) under the U.S. Endangered Species Act. NOAA Tech Memo NOAA-NMFS-SWFSC-539. https://repository. library.noaa.gov/view/noaa/4922 (accessed 25 April 2019)

Shaver DJ, Rubio C (2008) Post-nesting movement of wild and head-started Kemp's ridley sea turtles Lepidochelys kempii in the Gulf of Mexico. Endang Species Res 4: 43-55

Shimada T, Jones R, Limpus C, Hamann M (2012) Improving data retention and home range estimates by data-driven screening. Mar Ecol Prog Ser 457:171-180

Shimada T, Jones R, Limpus C, Groom R, Hamann M (2016) Long-term and seasonal patterns of sea turtle home ranges in warm coastal foraging habitats: implications for conservation. Mar Ecol Prog Ser 562:163-179

Silber GK, Adams JD, Bettridge S (2012) Vessel operator response to a voluntary measure for reducing collisions with whales. Endang Species Res 17:245-254

Small C, Nicholls RJ (2003) A global analysis of human settlement in coastal zones. J Coast Res 19:584-599

Stinson ML (1984) Biology of sea turtles in San Diego Bay, California, and in the northeastern Pacific Ocean. MS thesis. San Diego State University, San Diego, CA

* Sugiura N (1978) Further analysis of the data by Akaike's information criterion and the finite corrections. Commun Stat Theory Methods 7:13-26

* Thomson JA, Börger L, Christianen MJA, Esteban N, Laloë JO, Hays GC (2017) Implications of location accuracy and data volume for home range estimation and finescale movement analysis: comparing Argos and FastlocGPS tracking data. Mar Biol 164:1-9

Turner-Tomaszewicz C, Seminoff JA (2012) Turning off the heat: impacts of power plant decommissioning on green turtle research in San Diego Bay. Coast Manage 40:73-87

U.S. Fish and Wildlife Service (2006) San Diego Bay National Wildlife Refuge. Sweetwater marsh and south San Diego Bay units. Final comprehensive conservation plan and environmental impact statement. Vol I - August 2006. https://www.fws.gov/uploadedFiles/Region_8/NWRS/ Zone_1/San_Diego_Complex/San_Diego_Bay/ Sections/What_We_Do/Resouce_Management/OU1_-Burn_Ash/Administrative_Record/AR \% 200012\% 20 SDBNWR\%20Comprehensive \% 20Conservation $\% 20$ Plan\%20and\%20EIS.pdf (accessed 25 April 2019)

* Vanderlaan ASM, Taggart CT (2007) Vessel collisions with whales: the probability of lethal injury based on vessel speed. Mar Mamm Sci 23:144-156

Welch H, Hazen EL, Briscoe DK, Bograd SJ and others (2019) Environmental indicators to reduce loggerhead turtle bycatch offshore of Southern California. Ecol Indic 98:657-664

WWite NA, Sjöberg M (2002) Accuracy of satellite positions from free-ranging grey seals using ARGOS. Polar Biol 25:629-631

Whiting SD, Miller JD (1998) Short term foraging ranges of adult green turtles (Chelonia mydas). J Herpetol 32: 330-337

*Worton BJ (1989) Kernel methods for estimating the utilization distribution in home-range studies. Ecology 70 : 164-168

\begin{abstract}
APPENDIX.
Table A1. General linear models fitted to estimated core use area (50\% UD) of green turtles in San Diego Bay and associated corrected AIC values. All models included the intercept parameter. \# days: the number of days turtles were tracked, mass: body mass in $\mathrm{kg}$, period: pre- or post-period, mean.tmp: the mean water temperature at a weather buoy in the northern part of San Diego Bay at the middle of tag deployment, sd.tmp: the standard deviation of water temperature at a weather buoy in the northern part of San Diego Bay at the middle of tag deployment, month: numerical month. + indicates additive terms, $\times$ indicates interaction between 2 terms
\end{abstract}

\begin{tabular}{|lr|}
\hline Model & $\Delta \mathrm{AICC}$ \\
\hline \# days + mass + period + mean.tmp + sd.tmp + month & 19.0 \\
\# days + period + mean.tmp + sd.tmp + month & 13.0 \\
period + mean.tmp + sd.tmp + month & 8.7 \\
period + sd.tmp + month & 4.9 \\
sd.tmp + month & 2.4 \\
sd.tmp & 0.0 \\
period + sd.tmp + mean.tmp + month + sd.tmp $\times$ mean.tmp & 13.5 \\
period + month + sd.tmp + period $\times$ month & 8.9 \\
\hline
\end{tabular}

Editorial responsibility: Mark Hamann, Townsville, Queensland, Australia
Submitted: May 7, 2019; Accepted: January 28, 2020

Proofs received from author(s): February 21, 2020 